\title{
Horizontal Transfer of Vancomycin Resistance Gene From Enterococcus sp. in Milk
}

\author{
Luciana Furlaneto Maia (I), Márcia Regina Terra (I), Márcia Cristina \\ Furlaneto (II) \\ (I) UTFPR - Universidade Tecnológica Federal do Paraná (Av dos Pioneiros 3131 Londrina \\ PR), (II) UEL - Universidade Estadual de Londrina (Rodovia Celso Garcia Cid, Km 380, \\ Londrina-PR)
}

\section{Resumo}

A cadeia alimentar tem sido descrita como rota e difusão de microorganismos resistentes a antibiótico. Dentre os micro-organismos destacase as espécies de Enterococcus, por apresentarem resistência intrínseca, mediada por genes localizados em cromossomos ou adquirida, mediada por genes presentes em plasmídeos e transposons. Neste estudo avaliamos a transferência do gene vanA entre isolados de E. faecium e E. faecalis, via processo conjugativo in vitro em leite reconstituído. Para tanto, foi traçado o perfil genotípico e fenotípico dos isolados doadores E. faecalis 802 e E. faecium 924 e receptores E. faecalis 848, 872 e 906 . Como marcadores moleculares obtivemos os isolados doadores vanA+tetL- gelE- cpd- e receptores vanA- tetL+ gelE+cpd+. Todos os genes foram confirmados quanto a localização plasmídial ou cromossomal. O gene cpd codifica uma proteína denominada feromônio sexual expressa pelo receptor. A Concentração Inibitória Mínima para os antimicrobianos vancomicina e tetraciclina foi estabelecida segundo a metodologia de preconizada pelo CLSI. O processo de conjugação foi realizado em leite em pó reconstituído na razão de 1:1(doador: receptor), sob agitação de $80 \mathrm{rpm}$ a $37^{\circ} \mathrm{C}$ por 6 horas. A cada 2 horas, uma alíquota do co-cultivo foi retirado e semeado em meio MHA suplementado com tetraciclina $(16 \mu \mathrm{g} / \mathrm{mL})$ e vancomicina $(32 \mu \mathrm{g} / \mathrm{mL})$. Foi observado crescimento de colônias transconjugantes com todos os pares conjugativos e todos os tempos de co-cultivo, mesmo sendo o doador e receptor da mesma espécie e espécies diferentes. Os

\footnotetext{
Referência:

Luciana Furlaneto Maia, Márcia Regina Terra, Márcia Cristina Furlaneto. Horizontal Transfer of Vancomycin Resistance Gene From Enterococcus Sp. in Milk. In: Anais do 12을 Congresso Latinoamericano de Microbiologia e Higiene de Alimentos - MICROAL 2014 [= Blucher Food Science Proceedings, num.1, vol.1]. São Paulo: Editora Blucher, 2014.

DOI 10.5151/foodsci-microal-101
} 
transconjugantes foram confirmados pela técnica de PCR para a presença dos genes eleitos como marcadores moleculares. Também foi realizado o processo de conjugação com doador morto, excluindo a possibilidade de transformação. A estabilidade plasmidial dos transconjugantes foi realizada por repiques celulares consecutivos em meio sem pressão seletiva finalizando com meio contendo os antibióticos tetraciclina e vancomicina. Cem por cento das colônias transconjugantes mantiveram o plasmídeo. Este trabalho mostrou a disseminação de genes de resistência entre isolados de Enterococcus sp, quando presente em alimento, o que pode acarretar em um aumento da frequência de Enterococcus spp. resistentes à vancomicina e outros antimicrobianos, dificultando ainda mais sua terapêutica.

Palavras-Chave: Enterococcus, conjugação, alimento Agência de Fomento: Fundação Araucária e CNPq. 